Article

\title{
An Analysis of the Effects of Development-Restricted Areas on Land Price Using Spatial Analysis
}

\author{
Dongkwan Lee ${ }^{1 \oplus}$ and Choongik Choi ${ }^{2, *}$ \\ 1 Institute of Social Science, Kangwon National University, 1 Gangwondaehak-gil, Chuncheon 24341, Korea; \\ matoto@yonsei.ac.kr \\ 2 Department of Public Administration, Kangwon National University, 1 Gangwondaehak-gil, \\ Chuncheon 24341, Korea \\ * Correspondence: choich@kangwon.ac.kr; Tel.: +82-33-250-6813
}

check for updates

Citation: Lee, D.; Choi, C. An

Analysis of the Effects of

Development-Restricted Areas on Land Price Using Spatial Analysis. Land 2021, 10, 660. https://doi.org/ 10.3390/land 10060660

Academic Editors: Luca Salvati and Jefferey M. Sellers

Received: 11 May 2021

Accepted: 19 June 2021

Published: 21 June 2021

Publisher's Note: MDPI stays neutra with regard to jurisdictional claims in published maps and institutional affiliations.

Copyright: (c) 2021 by the authors. Licensee MDPI, Basel, Switzerland. This article is an open access article distributed under the terms and conditions of the Creative Commons Attribution (CC BY) license (https:// creativecommons.org/licenses/by/ $4.0 /)$

\begin{abstract}
The purpose of this study was to estimate the effects of development-restricted areas (DRAs) on land price. The study area used was Goyang city in South Korea, where DRAs occupy a large proportion of the city's administrative area. To examine the economic impact of the DRA, this study estimated log-linear regression models and calculated the difference between the land price determined within the DRA and the land price of the developed areas within buffers created by using a geographic information system (GIS). The results showed that a designation of DRA decreased land price, and that there was a large difference in the land price between the inner and the outer DRA, with a difference of USD $871 / \mathrm{m}^{2}$ in the average land price of the study area. These results serve as a reference for policymakers regarding land use in metropolitan areas in the future.
\end{abstract}

Keywords: development-restricted area; greenbelt; spatial analysis

\section{Introduction}

Recently, development-restricted areas (DRAs) have become an issue up for discussion in South Korea. A DRA, also called a greenbelt, is a green area set up for the purposes of improving the urban landscape and preserving the natural environment. It was initiated in the UK, and the concept was permanently established as an annular green area several miles wide around the city area according to the Greater London Plan of 1944. It is also one of the most restrictive forms of urban containment policy [1]. Greenbelts can protect cities and surrounding areas by acting as a natural buffer and mitigating air pollution through plants that are resistant to air pollution [2]. Thus, greenbelt policies have focused on preserving open space and controlling urban growth [3]. Currently, many greenbelt plans are being created all over the world to protect and conserve agricultural and natural spaces to cope with increasing urban sprawl [4-9].

The Korean government has strictly controlled and managed development activities by designating DRAs to prevent disorderly diffusion and provide a pleasant natural environment for urban residents. On the other hand, the DRAs can greatly affect property rights from a local government's point of view, due to the decrease in overall land prices and the limitation of development. It is generally believed that greenbelts can reduce land supply while raising land prices in South Korea. Since the greenbelt is considered to be a form of restriction of property rights, a designation of a greenbelt means depriving landowners of property rights, whereas releasing of the greenbelt restores property rights [10]. However, there is no clear-cut answer to this. There has been disagreement in previous studies on whether greenbelts positively or negatively affect land prices. Furthermore, it is difficult to conclude whether greenbelts are an effective policy tool or not, because the effectiveness of the greenbelt policy depends on local conditions of the land market, such as the size of developable lands between the core city and the greenbelt [11]. Although the greenbelt provides plenty of amenities for people, its effectiveness as a policy tool is disappearing [12]. 
The greenbelt is recognized as one of the difficult tasks that urban planners must overcome in constructing new towns where commuters can commute around large cities [13].

There is considerable controversy over the justification of the greenbelt policy because it creates uncertainty and irreversibility of land use through land-use change sanctions. Regarding this, Willis and Whitby [14] argued that the benefits of land value should exceed the value of the greenbelt. Furthermore, research on management plans and comprehensive plans concerning DRAs continue, focusing on the regulatory advantages of the greenbelt in the past. However, over time, cities have focused more on other functions of the greenbelt, such as protecting agricultural land and providing recreational resources. Currently, it is necessary to review and plan land use management in terms of land price in the context of economic effects. Land price here is an exchange value of land, which is the earth's surface including trees, minerals, and water, whereas property price is an exchange value of the real property, including land as well as houses or buildings [15].

Land ownership in South Korea's greenbelt remains a controversial topic and an under-researched area. Strict greenbelt regulations set limits on development, while most of the land remains in private ownership in South Korea. The various objectives of greenbelt landowners also need to be considered, whether for conservation and recreation or for investment and other purposes [16]. Due to this characteristic of the greenbelt, achieving a successful greenbelt policy depends on the separation of development rights from land ownership [17]. In the case of Canada, the greenbelt is almost entirely federally-owned, with the exception of the Greater Toronto Area's Greenbelt, to legally protect and keep the greenbelt in public ownership [18]. Although the benefits of a greenbelt are great, a dilemma may arise for owners of land within the greenbelt due to the strict restrictions on land use. Moreover, [19] suggests that an excessive number of implementation conditions in spatial planning discourages public and private investments in construction projects. Hence, it is important for spatial planning to provide adequate, professional-based land-use guidelines which account for public and private interests as well.

This study is a preliminary part of research that aims to bridge these gaps and provide insight. Taking the points mentioned above into account, this study explored the impact of the restriction of land development in the context of land use within metropolitan areas, particularly in the greenbelts of South Korea.

\section{Literature Review}

The literature research section focuses on: (1) the birth and role of the greenbelt within the cities, (2) how urban green area (UGA) improves the urban environment, (3) the relationship between UGA and the urban planning process, (4) the impact of UGA on land and property price, and (5) how previous studies were conducted, nationally and internationally.

There have been many studies conducted on the value of UGA, and the findings of previous studies provide evidence of UGA's benefits. First, about the birth and role of the greenbelt within the cities, the concept of greenbelts goes back to Ebenezer Howard's garden cities. The Development Plan for London (1919) was inspired by Howard's garden city, which called for green spaces in what were then the outer suburbs. In the case of their role, they provided public open spaces and recreational areas to establish a girdle of open space around the densely packed city. It prevented the spread of the city, maintained the urban landscape, and preserved the environment as well [20]. It is a well-known fact that UGA provides solutions to problems that may arise in cities as well. As previous studies have shown, UGA contributes to citizen's health and wellbeing [21,22], and the size of an UGA is positively associated with the bird migrant species richness as well [23]. The cooling effects of UGAs and water bodies are considered an essential part of reducing the heat island effect $[24,25]$. UGA is also an important criterion for measuring sustainability and it has positive relationships with the perceived restoration of citizens [26]. A recent study proved that UGA was related to racial disparity in disease infection rates, showing a significant association with a lower racial disparity in infection rates [27]. Recently, there were studies that demonstrated that the various functions of green space can be positively 
utilized to overcome the COVID-19 pandemic because people with access to green space have better health and wellbeing [28-30].

Second, concerning how greenbelts can improve the urban environment, the effect of greenbelts can present themselves in two ways: first, the role of greenbelts in preventing urban proliferation; and second, the effect of greenbelts on the surrounding land prices. Regarding the first role of greenbelts, Benítez et al. [31] insist that greenbelts function as a reserve of open spaces around urban concentrations by conserving areas of natural vegetation and agricultural lands around cities. Greenbelts are also used as a device to protect farms from urban proliferation [32-34]. The authors also suggested new functions of greenbelts, such as reducing the negative potential impact of climate change, urban islands, and flood risks around the cities [35]. It is necessary to consider other functions of greenbelts as well, for example, preserving open space, agricultural land, providing recreational resources, or other economic and social tools to make a successful greenbelt policy [36-38]. Urbanization, which causes population growth, negatively affects greenbelts due to the construction of urban infrastructure and pressure on the urban ecosystem [39]. On the other hand, it is not clear whether greenbelts have successfully prevented urban sprawl at a regional level or within urban centers [40].

Third, in terms of the relationship between UGA and the urban planning process, many local and world organizations provide guidelines to implement and promote UGA for sustainable urban development. The World Health Organization (WHO) supports green spaces and nature-based solutions to increase the quality of life in urban areas by improving the wellbeing and health of urban residents. They introduced four approaches that can be considered within the urban planning process: (1) be clear about the objectives of green space planning, (2) make use of the urban and local planning context and frameworks, (3) have a long-term perspective and remain flexible, and (4) consider green space projects to be a public health and social investment [41]. The Food and Agriculture Organization (FAO) of the United Nations supports the development of strategic planning to protect urban forestry [42]. At the regional and global level, various organizations are providing guidelines related to the planning process to protect urban green areas.

Fourth, in the connection with the impact of the greenbelt on the land and property prices, expectations for high amenity value derived from surrounding preserved open space heightened the values of properties near greenbelts [43]. When forests and parks are considered urban amenities, externality effects are generated and positively influence the value of housing units [44]. Jung et al. [45] found that parks generated positive externalities to housing prices and could revitalize real-estate markets by increasing residential property values and property tax revenues. Consequently, public services improved, resulting in the enhancement of the neighborhood in the form of a virtuous cycle. Nicholls and Crompton [46] showed that the greenbelt had a positive impact on property sales values and that adjacency to a greenbelt had a significant value premium with the hedonic price method in Austin, Texas. Depending on the distance to the greenbelt and its location, there was a premium of $5.4 \%$ to $20.2 \%$ on the average of all homes in the area. Similarly, Netusil [47] found that in Portland, Oregon, the effect of environmental zoning and amenities on property's sale price varied depending on type of environmental zoning and property location, amenity type, and proximity to greenbelts using the hedonic price method. Vyn [48] found that property values in residential areas across greenbelts increased by an average of $4.2 \%$ with the hedonic price approach because of Ontario's greenbelt legislation, which prevents development within rural areas around the Greater Toronto Area (GTA). These studies support that greenbelts are associated with price premiums and an increase in the value of properties. However, this is not always the case. Bono et al. [49] investigated the relationship between housing prices and access to the greenbelt in Carrollton, Georgia. They found that access to the greenbelt lowered housing sale prices using the hedonic price method. Regarding the positive impact of green areas, several studies have demonstrated that green areas have a positive effect on property prices. Bockarjova et al. [50] found that green infrastructure had a positive impact on property price in the areas surrounding 
it and that it increased property prices up to $20 \%$ compared to properties in unaffected areas. Anderson and West [51] examined the effects of proximity to open spaces, such as neighborhood parks, special parks, golf courses, and cemeteries, on the sales price and found that neighborhood parks increased property prices up to three times higher than the average, while special parks increased prices up to two-thirds higher. [52-55] also showed the positive effect of green areas on property prices in the surrounding area.

It was found when the surrounding greenbelt was lifted, versus when it was not lifted, affects the land price differently. Moreover, there is a difference between the proximity to greenbelts negatively affecting land prices and the proximity to parks outside greenbelts positively affecting surrounding land prices. Lee and Yoon [56] found that the release of greenbelts had a positive effect on increasing the land price by $11.2 \%$ every $100 \mathrm{~m}$ within a $500 \mathrm{~m}$ buffer closer to the released greenbelt site on non-greenbelt land in Wirye New Town, South Korea through random-coefficient multilevel regression modeling. On the other hand, Deaton and Vyn [57] used a hedonic model and found that the influence of greenbelt legislation on the property value, based on the proximity of properties to the GTA, was negative within $10 \mathrm{~km}$ of the GTA and positive over $50 \mathrm{~km}$ from the GTA. In South Korea, as the location of an apartment gets closer to a greenbelt, the monthly rents decrease, showing a centripetal residential location pattern [58]. Hence, the distance from greenbelts is an important factor that influences apartment prices. Specifically, the distance from greenbelts is negatively associated with apartment prices, while the distance from the central business district increases apartment prices [57]. Morano et al. [59] found, via evolutionary polynomial regression, that a series of different elements of urban green space, such as tree-lined avenues, public green areas, and the existence of a view, differently impacted housing prices in the Flaminio district of Rome.

From the literature, it was found that national and international studies related to the greenbelt were conducted, identifying points that can make academic contributions. First, the controversy over the effectiveness of greenbelts continues. It is not clear whether greenbelts have successfully prevented urban sprawl, and the effect is such that it can appear differently (positively or negatively) depending on location or conditions. In line with Han et al. [60], greenbelt policy has a significant impact on urban land development, whereas the effect of greenbelt deregulation is not as obvious and depends on the surrounding location. Second, detailed price analysis is necessary to establish how the land price is affected by greenbelts. Third, the way in which land prices are affected by proximity to greenbelts should be considered. From this point of view, the example of Korea, where there is much controversy regarding greenbelts, can be useful for future studies.

There is a limitation in that these studies cannot show how the setting of the greenbelt affects property prices within the greenbelt. When lands are designated as greenbelts, surrounding buildings and land are affected, and there are many existing studies on this subject. However, the person most affected by the designation of the greenbelt is the landowner within the greenbelt. Research on their impact is difficult to find and needs to be considered. The main aims of this research are as follows: (1) finding the impact of regulation that restricts land development on land price by adopting regression models; (2) determining the effect of proximity to greenbelts by calculating the difference in land price based on distance from the boundary; and (3) estimating the total effect of greenbelts on land price in the study area. To address these issues, in this study we examined the economic effects of the DRA in three districts: Seo-gu, Dong-gu, and Deokyang-gu in Goyang city, South Korea, where DRAs occupy a large proportion of the administrative area. This study also used spatial analysis technology to support the assumption that the inner and outer boundaries of greenbelts affect the land price, especially based on the distance. This study is organized into stages, as shown in Figure 1 below. 


\section{Theoretical review of greenbelt}

\section{Literature research}

- Background of greenbelt

- Green areas in urban areas

- Impacts of greenbelt on property prices

- Regulations of greenbelt

- Greenbelts in South Korea

\section{Introduction of study area}

\section{Data and Methods}

- Land price data and GIS layers

- 500m, 1000m, 500-1000 buffers

\section{Analysis}

- Estimating the impact of the Development Restricted Area on the land price

- Comparison of land prices based on buffers and locations

\section{Conclusion and Discussions}

Figure 1. Flowchart of the stages of this study's research.

\section{Greenbelts in South Korea}

In South Korea, a DRA is, according to the National Land Planning and Utilization Act, a zone applied only to urban areas. It was designated for some of the green areas outside of cities to prevent the city from spreading to the outskirts in a disorderly manner. In non-urban agricultural and forest areas and urban areas, no DRAs are designated in residential or industrial areas. When a DRA is lifted, it is designated as a green area and action restrictions on the green area are applied. Since the DRA was designated to restrict development, land-use restrictions are stronger than in other regions [61]. Specifically, the land-use zoning of the greenbelt area is DRA. The greenbelt prohibits any development activity. Exceptionally, specific developmental actions are possible such as essential facilities passing through the DRA, defense or military facilities, correctional facilities, and facilities that can help preserve and manage DRAs, etc. 
Greenbelts were first conceived of in the UK in the 1950s, and were introduced in South Korea in 1971. The Korean government designated a circular area $\left(467 \mathrm{~km}^{2}\right)$, with a radius of $2-10 \mathrm{~km}$, outside of the center of Seoul as a greenbelt through a public notice. The area of the designated greenbelt reached $77 \%$ of the area of Seoul $\left(605 \mathrm{~km}^{2}\right)$. Until 1977, $5.4 \%$ of the country, $5397 \mathrm{~km}^{2}$, was designated as greenbelts in the name of restraining city expansion. Greenbelts were used as a means of preventing the rapid increase of the urban population and the excessive expansion of urban areas. They also contributed to the development of healthy cities that preserved the natural environment around them in harmony with nature. However, for less than one year at the time of designation, the DRA was designated without field investigation. Local characteristics were not sufficiently considered under the leadership of the central government. In particular, greenbelts were uniformly designated from large cities such as Seoul, with a population of more than 5 million at the time, to Jeju City, which had a population of only 150,000. The designation of $5.4 \%$ of land as a DRA, without sufficient preliminary preparation and theoretical support, proved problematic [62].

To the extent that it does not violate the purpose of the designation of a DRA, development is possible with the permission of the permit holder (provincial governor or the Minister of Land, Infrastructure, and Transport). Greenbelts are divided into production green areas and blocked green areas. Some economic activities, such as farming, livestock, and forestry, are possible in the production green areas. Blocked green space prevents unlimited expansion of urban areas, along with providing environmental protection.

Greenbelts were partially lifted starting in 1999 and had decreased to $3846 \mathrm{~km}^{2}$ by the end of 2019. Among the nationwide DRAs, it was decided to completely remove greenbelts from seven small- and medium-sized urban areas. In the case of other metropolitan cities, DRAs were maintained. Large areas of greenbelts were lifted in the name of expanding national rental housing and promoting balanced regional development. In particular, a DRA was released to proceed with the construction of one million national rental housing units. To promote the national project "Bogeumjari Housing", and current projects of local governments, the total area of cancellation was increased.

Since the enactment of the Special Act on the Designation and Management of Restricted Development Zones in 2000, there has been no additional designation and only cancellation or reduction has occurred. From the end of 2004, the government established the "Greenbelt Land Agreement Purchase System", which manages greenbelt land purchases. To conserve and create green areas, the government is purchasing land where there is high development pressure, such as places where there is a high risk of damage to the natural environment, places that are essential for maintaining greenbelts, and areas where greenbelts are scheduled to be lifted. The current government maintains its position to preserve greenbelts [63].

\section{Study Area}

The spatial scope for this study includes the entirety of Goyang city and the DRAs and military facility protection areas spanning Seo-gu, Dong-gu, and Deokyang-gu as shown in Figure 2. In the case of Goyang, the administrative area is $266.405 \mathrm{~km}^{2}$, whereas the area of the greenbelt is $119.27 \mathrm{~km}^{2}$. As the ratio of the DRA to the administrative area is $44.77 \%$, the greenbelt has a great influence on the activities of local governments.

Goyang city is located in the northwestern part of Gyeonggi-do, with a population of 1,075,841 as of September 2020, and is the second-most populous city after Suwon as a basic municipality. It comprises of three districts: Seo-gu, Dong-gu, and Deokyang-gu. Goyang city is the largest city in the northern part of Gyeonggi province, and its closest distance to North Korea is only $10 \mathrm{~km}$, which is also close to the armistice line and the Demilitarized Zone (DMZ). 
In the case of Dong-gu and Seo-gu, there is a sense of sameness as a new city and the city area is not particularly separated. Deokyang-gu is a small- and medium-sized urban district that is linearly connected along roads and railroads, and internal fragmentation is severe. The greenbelt in Goyang city was designated three times since 1971, when $65.08 \mathrm{~km}^{2}$ was designated as a greenbelt and $69.4 \mathrm{~km}^{2}$ were included in the DRA in 1972. In March 1995, an area of $0.05 \mathrm{~km}^{2}$ included in Jichuk-dong, Deokyang-gu was incorporated into Eunpyeong-gu, Seoul, and the area of the DRA decreased. Thus, the greenbelt area in Goyang city totaled $134.43 \mathrm{~km}^{2}$. Since then, the greenbelt has been steadily lifted and 27 changes have been made as of 2018; a total area of $15.164 \mathrm{~km}^{2}$ was lifted, and $119.266 \mathrm{~km}^{2}$ are currently designated as a greenbelt [64].

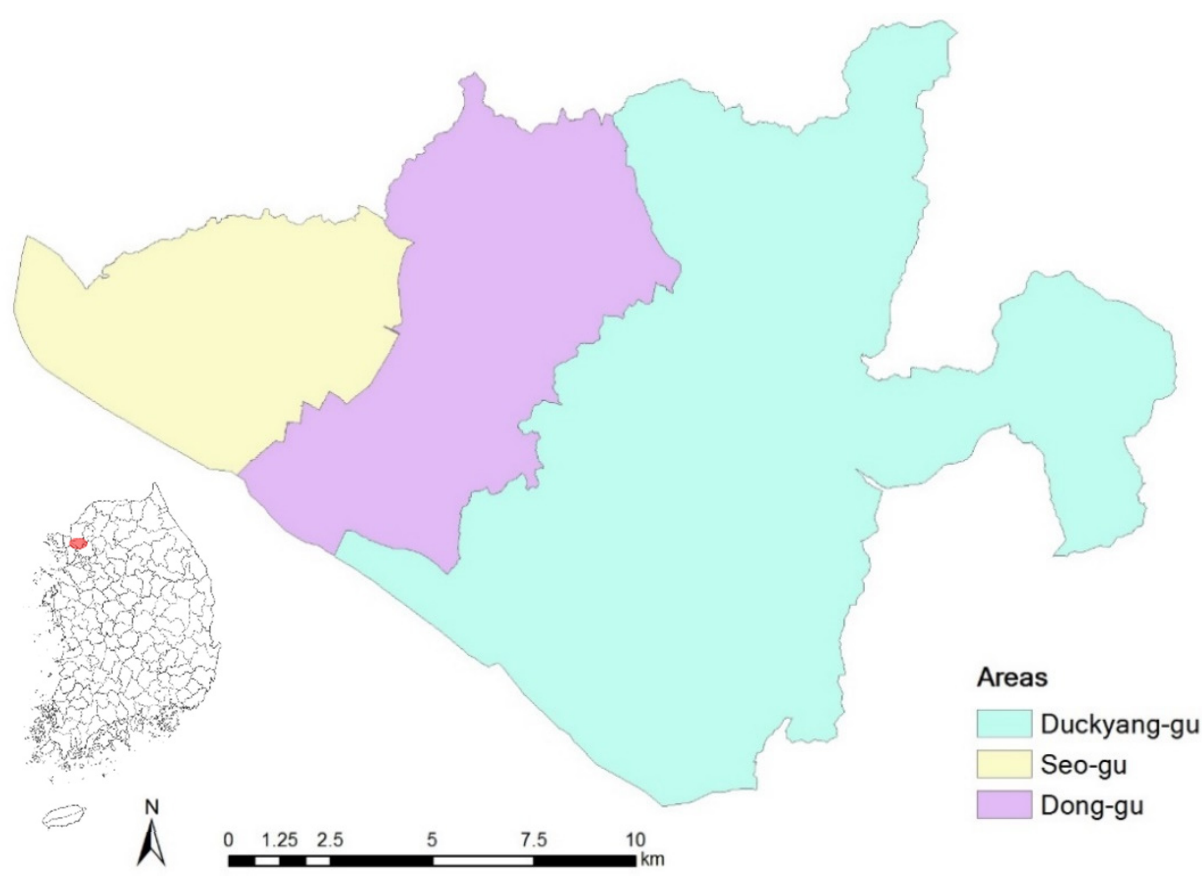

Figure 2. Location of three areas in Goyang city: Seo-gu, Dong-gu, and Deokyang-gu.

\section{Data and Methods}

\subsection{Data}

Individual land price data for Goyang city (as of January 2018), provided by the Goyang city government, was utilized. GIS on the administrative boundary layers (Goyang city, Seo-gu, Dong-gu, and Deokyang-gu layer) and restricted area layers (DRA layer, military facility, and protected area) of Goyang city were used as data for spatial analysis. While processing the data, the published land price data and GIS data were matched based on a unique number for each parcel. The land price for 178,000 parcels was utilized. The maximum land price of the site was USD $10,664 / \mathrm{m}^{2}$. The minimum land price was USD $0 / \mathrm{m}^{2}$ because public land, such as streets and roads, were included. Since this public land, priced at USD $0 / \mathrm{m}^{2}$, was not transferred and not valued accurately, it was excluded from the analysis. The average land price was USD $485 / \mathrm{m}^{2}$. As a result of mapping the data of the published land price in Goyang city, the distribution of the decision land price was determined, as shown in Figure 3. In Seo-gu, Dong-gu, and Deokyang-gu, there was a significant difference between the land prices within the DRA and the developed area. High land prices formed around the developed areas, and the areas surrounded by the boundaries of the DRA showed very low land prices. 


\subsection{Methods}

To investigate the impact on the land price of the DRA, this study attempted to analyze it in two ways. First, log-linear regressions were adopted to investigate how DRA affected the land price in the study area. Since the independent variable DRA was a dummy variable and made the data more symmetrical and normal, the log-linear models were created by taking the logarithm of the dependent variable, land price, and expressed it as:

$$
\log (y)=\alpha+\beta_{1} x
$$

where $y$ is the dependent variable and the land price, while $\alpha$ is an intercept and $\beta_{1}$ is a coefficient of DRA. Moreover, independent variables, such as distance from the DRA boundary line and distance from the nearest subway station, considered the effects of proximity and accessibility in the regression models.

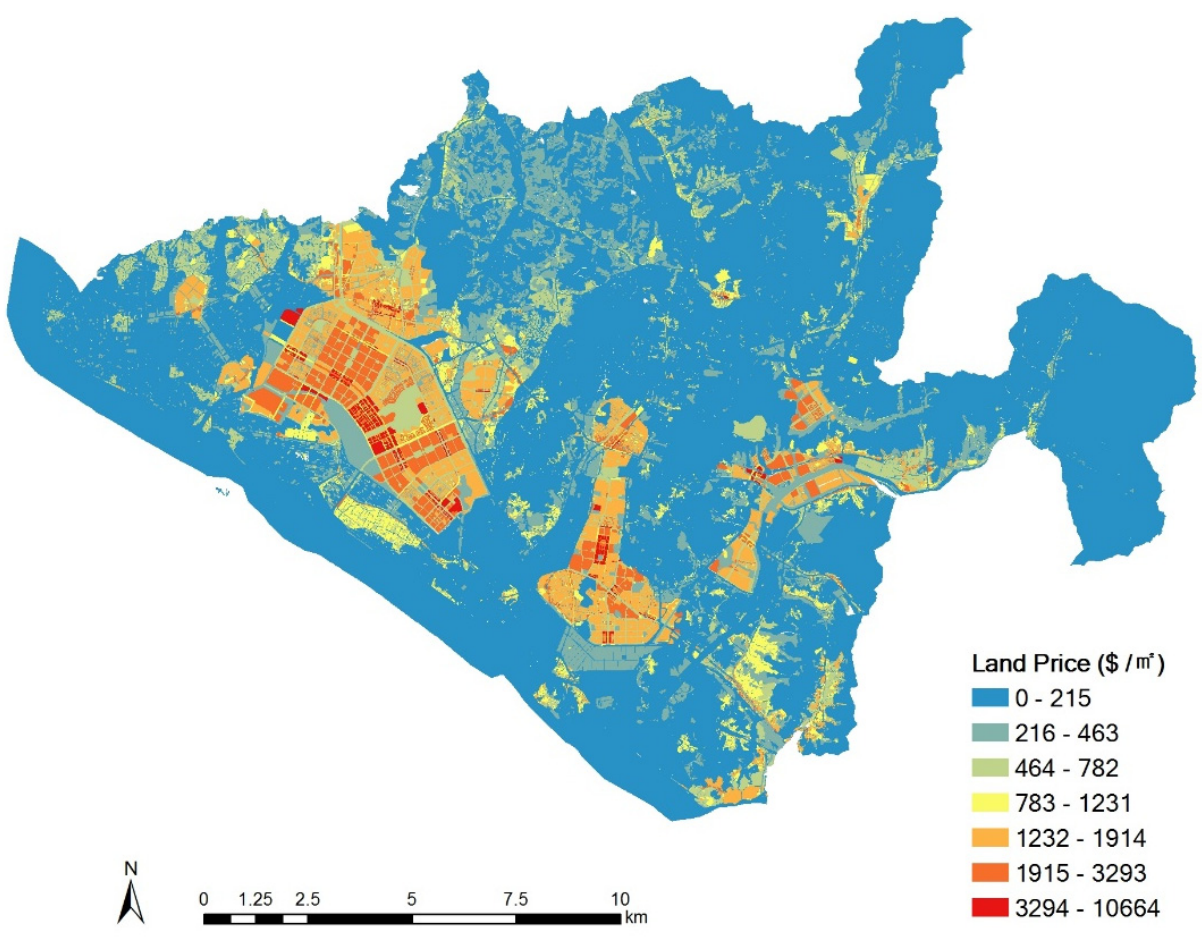

Figure 3. Distribution of individual public land prices.

Second, this study also compared the land price in the DRA with the land price in the area adjacent to the DRA in order to determine the effect of the DRA on land price. The land prices in the buffer, which are not too far from the boundary line of the DRA, of the areas which were recently lifted from the DRA were compared. For the comparison, buffers were created based on the boundary line of the DRA, and the land price in the DRA in the buffer was compared with the land price outside the DRA.

To implement these methods, a geographic information system (GIS) was adopted, and four points were made on the DRA boundary by selecting areas that were recently released. Buffers were created based on a $500 \mathrm{~m}$ radius, $1000 \mathrm{~m}$ radius, and $500 \mathrm{~m}$ to $1000 \mathrm{~m}$ radius. The points were located at the boundary of the greenbelt, so when forming a buffer, the areas inside and outside the greenbelt were included. 
The spatial analysis was carried out via the following procedure. First, the land price data and the parcel data in Goyang-si were matched according to the unique number. Second, to compare the land prices within the DRA with the land prices in the region where the DRA was lifted, we decided to select and compare four boundary areas from the region where the DRA was recently lifted, as shown in Figure 4.

Third, buffers of $500 \mathrm{~m}, 1000 \mathrm{~m}$, and 500 to $1000 \mathrm{~m}$ were created around the four points. Regarding the size of the buffer, the proximity effects on nearby properties, varying from a short walking distance to a 3-5-min walking distance, were used for estimating the impact from the boundary [65]. Lee and Yoon [56] used a $500 \mathrm{~m}$ buffer and found that the release of the greenbelt had the positive effect of increasing land prices. Han et al. [66] adopted a $500 \mathrm{~m}$ buffer for the inner and outer boundaries of the greenbelt. In the present study, buffers with a radius of $500 \mathrm{~m}, 1000 \mathrm{~m}$, and 500-1000 m were created in four designated locations for analysis. In comparing the land prices in the $500 \mathrm{~m}$ buffer and the $1000 \mathrm{~m}$ buffer, we assumed that the distance from the DAR would affect the land price. However, in the case of a buffer with a radius of $1000 \mathrm{~m}$, since the land price in the buffer of $500 \mathrm{~m}$ was also included, a buffer of $500 \mathrm{~m}$ to $1000 \mathrm{~m}$ was created separately to identify and confirm this.

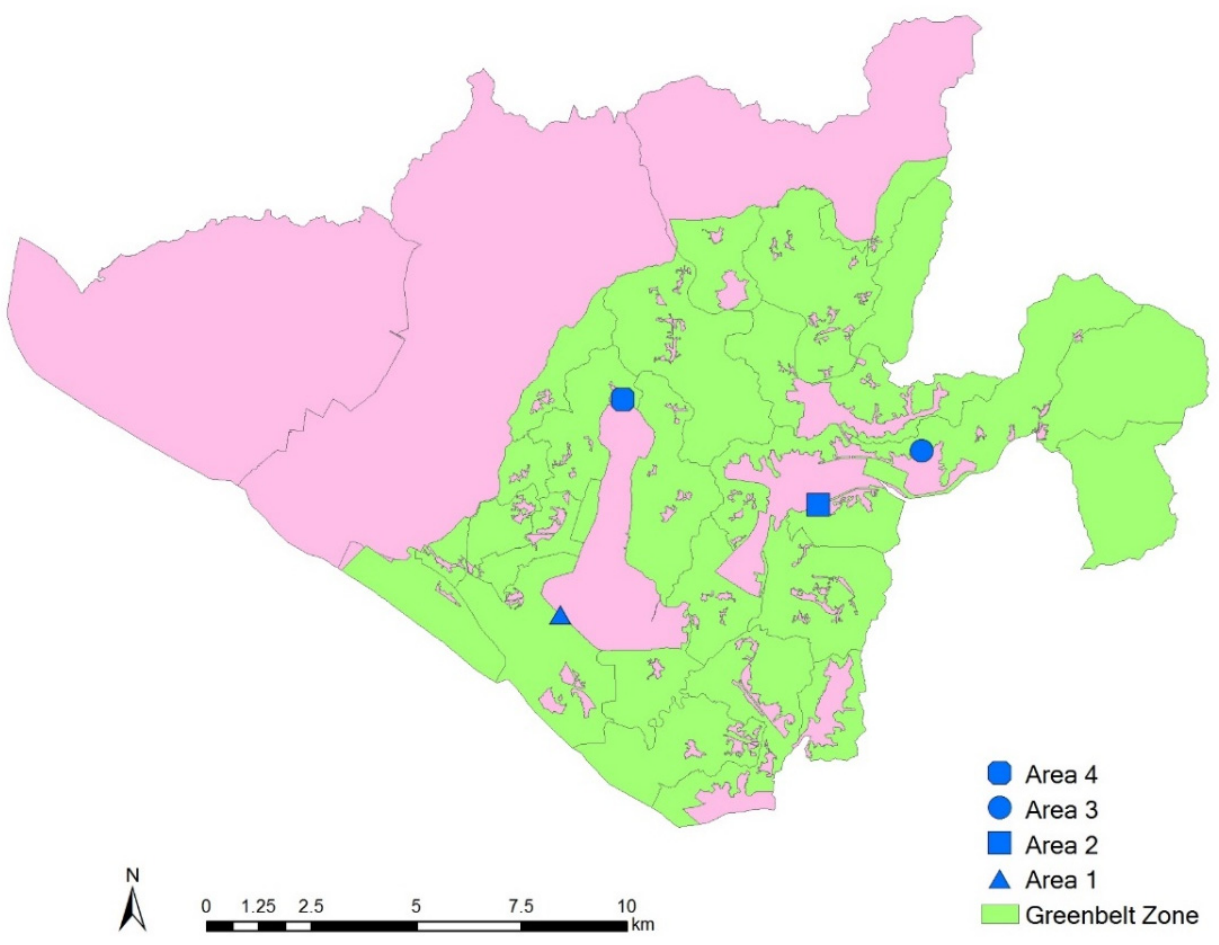

Figure 4. Targeted areas.

Fourth, the land prices of the areas included in each buffer were divided into areas included in and excluded from the DRA, and an average was created and compared.

A $500 \mathrm{~m}, 1000 \mathrm{~m}$, and 500-1000 m sized buffer was created around each of the selected points and each buffer was used to calculate the difference between the decision land price in the DRA and the decision land price in the outside region (calculated based on the exchange rate: USD $1=\mathrm{KRW} 1100$ ). As shown in Figure 5, buffers were created in each region. Areas marked in green were areas included in the DRA, and red areas corresponded to developed areas. Therefore, we could compare the average values of the publicly announced land prices in these two areas in the buffer. The descriptive statistics for variables in the areas are presented in Table 1. 


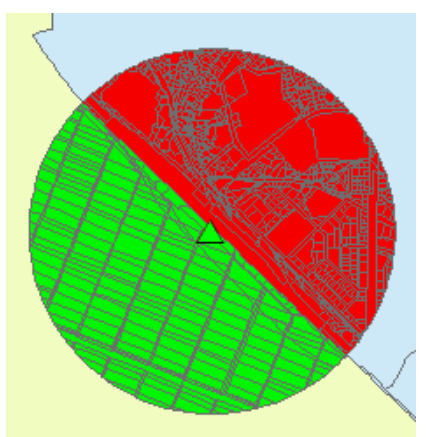

$500 \mathrm{~m}$ buffer in Area 1

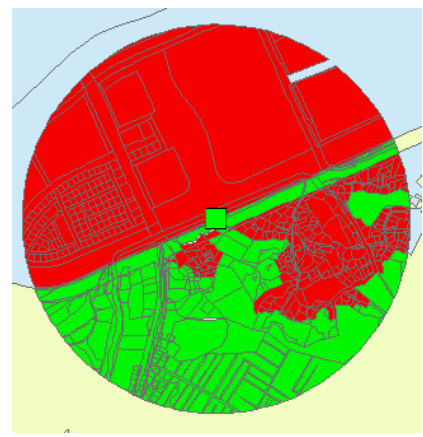

$500 \mathrm{~m}$ buffer in Area 2

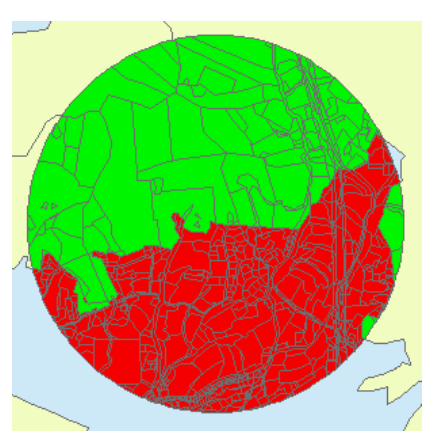

$500 \mathrm{~m}$ buffer in Area 3

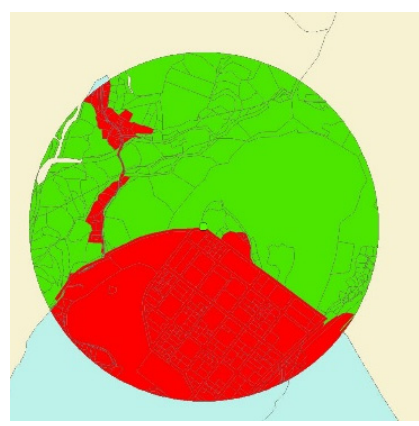

$500 \mathrm{~m}$ buffer in Area 4

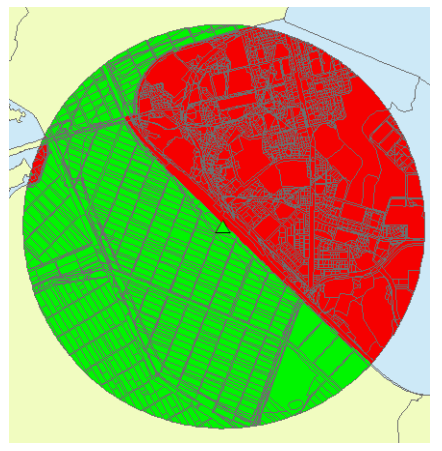

1000 m buffer in Area 1

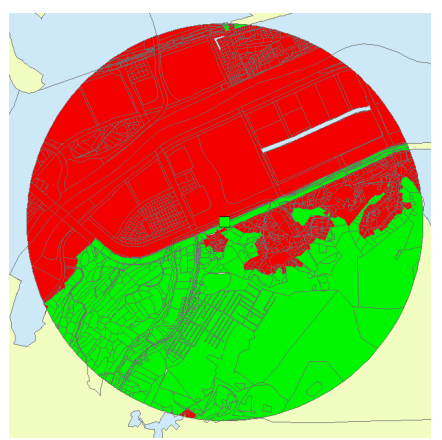

$1000 \mathrm{~m}$ buffer in Area 2

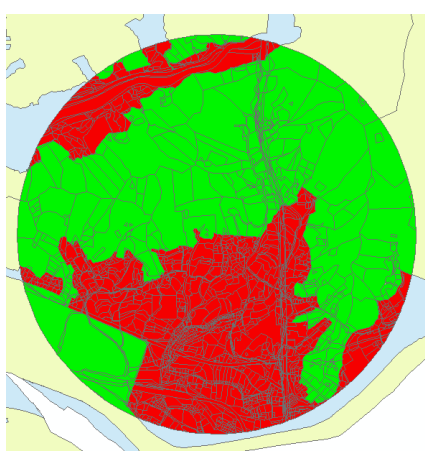

$1000 \mathrm{~m}$ buffer in Area 3

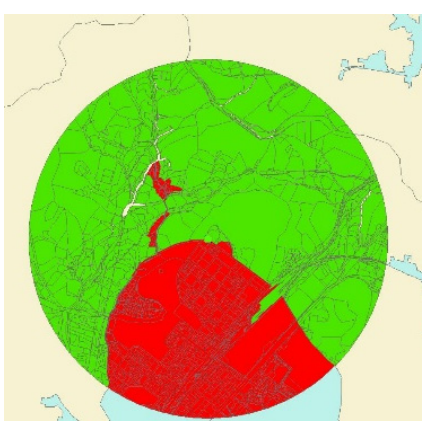

1000 m buffer in Area 4

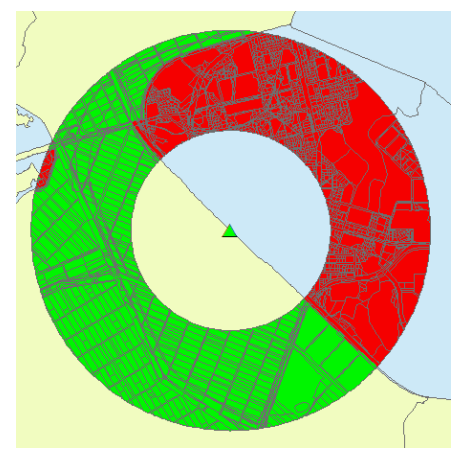

500-1000 m buffer in Area 1

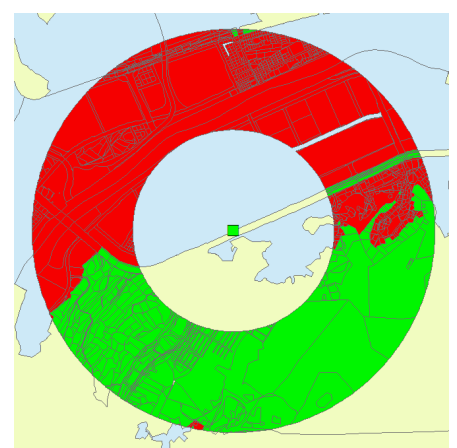

500-1000 m buffer in Area 2

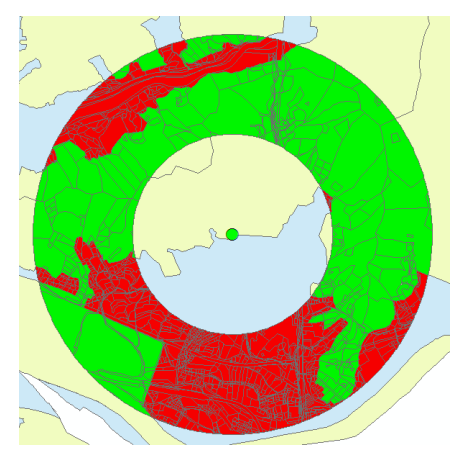

500-1000 m buffer in Area 3

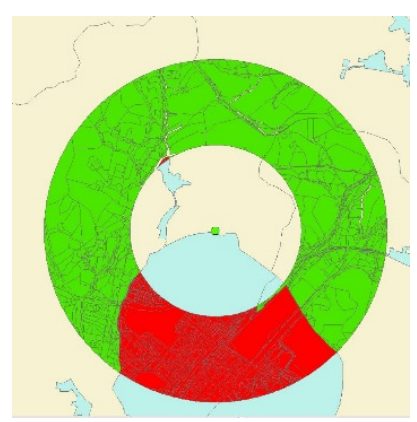

500-1000 m buffer in Area 4

Figure 5. Locations of buffers. 
Table 1. Descriptive statistics for each area (within $1000 \mathrm{~m}$ radius from the center of the area).

\begin{tabular}{|c|c|c|c|c|}
\hline Variable & Min & Max & Mean & Std. Dev \\
\hline \multicolumn{5}{|c|}{ Area 1} \\
\hline LandPrice (USD / m²) & 13.2 & 4474.8 & 1088.9 & 888.2 \\
\hline NDRA ( 1 or 0$)$ & 0 & 1 & 0.68 & 0.46 \\
\hline Dist_GL (m) & 0.3 & 996.8 & 436.4 & 237.2 \\
\hline Dist_sub (m) & 2.13 & 1191 & 557.8 & 232.2 \\
\hline $\operatorname{ReGe}(1$ or 0$)$ & 0 & 1 & 0.46 & 0.50 \\
\hline ReSer ( 1 or 0$)$ & 0 & 1 & 0.02 & 0.46 \\
\hline $\operatorname{ReSi}(1$ or 0$)$ & 0 & 1 & 0.39 & 0.14 \\
\hline SchEnv (1 or 0$)$ & 0 & 1 & 0.64 & 0.49 \\
\hline $\mathrm{SZ}(1$ or 0$)$ & 0 & 1 & 0.08 & 0.48 \\
\hline Pcul (1 or 0$)$ & 0 & 1 & 0.08 & 0.27 \\
\hline Dist_Cen (m) & 1436.9 & 3425.6 & 2243.9 & 467.6 \\
\hline \multicolumn{5}{|c|}{ Area 2} \\
\hline LandPrice $\left(\mathrm{USD} / \mathrm{m}^{2}\right)$ & 81.6 & 3256.0 & 895.1 & 715.8 \\
\hline NDRA (1 or 0$)$ & 0 & 1 & 0.63 & 0.48 \\
\hline Dist_GL (m) & 0.4 & 958.9 & 344.3 & 270 \\
\hline Dist_sub (m) & 367 & 5667.4 & 4759.5 & 558.2 \\
\hline ReSer $(1$ or 0$)$ & 0 & 1 & 0.09 & 0.28 \\
\hline SchEnv (1 or 0$)$ & 0 & 1 & 0.23 & 0.42 \\
\hline Pcul (1 or 0$)$ & 0 & 1 & 0.04 & 0.19 \\
\hline Dist_Cen (m) & 4196.6 & 6190.6 & 5259.3 & 465.1 \\
\hline \multicolumn{5}{|c|}{ Area 3} \\
\hline LandPrice (USD/m²) & 54.5 & 4565.0 & 1022.6 & 899.4 \\
\hline NDRA ( 1 or 0 ) & 0 & 1 & 0.84 & 0.36 \\
\hline Dist_GL (m) & 0.14 & 470 & 132 & 110 \\
\hline Dist_sub (m) & 6099 & 8071 & 6847 & 411 \\
\hline ReGe $(1$ or 0$)$ & 0 & 1 & 0.13 & 0.34 \\
\hline SchEnv ( 1 or 0$)$ & 0 & 1 & 0.50 & 0.50 \\
\hline Pcul (1 or 0$)$ & 0 & 1 & 0.10 & 0.30 \\
\hline Dist_Cen (m) & 6833.2 & 8793.7 & 7781.7 & 387.1 \\
\hline \multicolumn{5}{|c|}{ Area 4} \\
\hline LandPrice (USD/m²) & 112.2 & 484.0 & 931.0 & 842.1 \\
\hline NDRA ( 1 or 0$)$ & 0 & 1 & 0.56 & 0.49 \\
\hline Dist_GL (m) & 0.8 & 894 & 250 & 185 \\
\hline Dist_sub (m) & 2776 & 4762 & 3591 & 465 \\
\hline URD (1 or 0$)$ & 0 & 1 & 0.28 & 0.45 \\
\hline MMD (1 or 0$)$ & 0 & 1 & 0.57 & 0.50 \\
\hline REIZ (1 or 0$)$ & 0 & 1 & 0.10 & 0.30 \\
\hline SEIA ( 1 or 0$)$ & 0 & 1 & 0.14 & 0.34 \\
\hline
\end{tabular}


Table 1. Cont.

\begin{tabular}{ccccc}
\hline Variable & Min & Max & Mean & Std. Dev \\
\hline SF $(1$ or 0$)$ & 0 & 1 & 0.41 & 0.49 \\
\hline PCSF $(1$ or 0$)$ & 0 & 1 & 0.04 & 0.19 \\
\hline Dist_Cen $(\mathrm{m})$ & 1942.2 & 3939.1 & 2669.5 & 492.6 \\
\hline
\end{tabular}

NDRA: not development restricted area (if land is located within DRA then 0, otherwise 1); Dist_GL: distance from the nearest greenbelt line; Dist_sub: distance from the nearest subway station; URD: urban renewal district; MMD: mountain management district; REIZ: residential environment improvement zone; SEIA: school environment improvement area; PCSF: public culture and sports facilities; SF: space facilities such as square, park, green space, amusement park, and public space; and Dist_Cen: distance from the city center.

\section{Results}

\subsection{Log-Linear Regression Models}

As shown in Table 2, regression models were created for each buffer in the four regions (from Area 1 to 4 ). Here, the exponentiated coefficient $\exp \left(\beta_{1}\right)$ for the land price was the ratio of the expected mean for the land price not in DRA over the expected mean for the land price of the parcels in the DRA [67]. Based on location (four areas) and distance of the buffer (three types), a total of 12 regression models were estimated and presented in Table 2 . To deal with the multicollinearity issue, the highly correlated independent variables were removed and variables with high variance inflation factors (VIF) were dropped from the models as well.

Table 2. Regression models for each area.

\begin{tabular}{|c|c|c|c|}
\hline Buffer Size & \multirow{2}{*}{ Model } & Adj. & \multirow{2}{*}{ DF } \\
\hline (m) & & R-Square & \\
\hline \multicolumn{4}{|c|}{ Area 1} \\
\hline 500 & $\begin{array}{l}\log (\text { LandPrice })=11.61+2.2 \times \mathrm{DRA}-7.5 \times 10^{-5} \times \mathrm{NDRA} \text { _G }+1.9 \times 10^{-4} \times \\
\text { Dist_sub }-0.2 \times \mathrm{URD}-0.08 \times \mathrm{MMD}+0.27 \times \mathrm{REIZ}+0.2 \times \mathrm{SEIA}-0.6 \times \mathrm{SF}\end{array}$ & 0.75 & 1230 \\
\hline 1000 & $\begin{array}{l}\log (\text { LandPrice })=12.2+2.2 \times \mathrm{NDRA}-5.02 \times 10^{-4} \times \mathrm{NDRA} \text {.G }-3.9 \times 10^{-4} \\
\times \text { Dist_sub }+0.25 \times \mathrm{URD}-0.57 \times \mathrm{MMD}-3.2 \times 10^{-4} \times \text { Dist_Cen }\end{array}$ & 0.78 & 4391 \\
\hline 500-1000 & $\begin{array}{l}\log (\text { LandPrice })=11.4+1.8 \times \mathrm{NDRA}+3.6 \times 10^{-4} \times \mathrm{NDRA} \text { _G }+3.1 \times 10^{-4} \times \\
\text { Dist_sub }+3.3 \times \mathrm{URD}-0.55 \times \mathrm{MMD}+0.18 \times \mathrm{REIZ}-0.41 \times \mathrm{SF}\end{array}$ & 0.79 & 3329 \\
\hline \multicolumn{4}{|c|}{ Area 2} \\
\hline 500 & $\begin{array}{l}\log (\text { LandPrice })=16.4+1.6 \times \mathrm{NDRA}+6.7 \times 10^{-5} \times \mathrm{NDRA} \text {.G }-6.2 \times 10^{-4} \times \\
\text { Dist_sub }-0.92 \times \mathrm{MMD}-0.4 \times \mathrm{PCSF}-2.5 \times 10^{-4} \times \text { Dist_Cen }\end{array}$ & 0.54 & 921 \\
\hline 1000 & $\begin{array}{c}\log (\operatorname{LandPrice})=12.15+1.5 \times \mathrm{NDRA}+8.9 \times 10^{-6} \times \mathrm{NDRA} \text {.G }+1.2 \times 10^{-4} \times \\
\text { Dist_sub }-1.2-5.3 \times \mathrm{PCSF}-5.4 \times 10^{-4} \times \text { Dist_Cen }\end{array}$ & 0.61 & 2292 \\
\hline 500-1000 & $\begin{array}{l}\log (\text { LandPrice })=12+1.5 \times \mathrm{NDRA}+1.9 \times 10^{-4} \times \mathrm{NDRA} \text {.G }+1.8 \times 10^{-4} \times \\
\text { Dist_sub }-1.6 \times \mathrm{MMD}-0.6 \times \mathrm{PCSF}-1.6 \times 10^{-4} \times \text { Dist_Cen }\end{array}$ & 0.65 & 1549 \\
\hline \multicolumn{4}{|c|}{ Area 3} \\
\hline 500 & $\begin{array}{l}\log (\text { LandPrice })=17.81+0.8 \times \text { NDRA }+1.0 \times 10^{-3} \times \text { NDRA_G }-9.0 \times 10^{-4} \times \\
\text { Dist_sub }\end{array}$ & 0.38 & 832 \\
\hline 1000 & $\begin{array}{l}\log (\text { LandPrice })=17.2+0.8 \times \mathrm{NDRA}+1.2 \times 10^{-3} \times \mathrm{NDRA} \text { _G }-1.0 \times 10^{-4} \times \\
\text { Dist_sub }-1.8 \times \mathrm{MMD}+0.12 \times \mathrm{SEIA}-2.1 \times 10^{-4} \times \text { Dist_Cen }\end{array}$ & 0.6 & 2438 \\
\hline 500-1000 & $\begin{array}{l}\log (\text { LandPrice })=17.9+0.9 \times \text { NDRA }+7.5 \times 10^{-4} \times \text { NDRA_G }-1.1 \times 10^{-3} \times \\
\text { Dist_sub }-1.7 \times \mathrm{MMD}+0.09 \times \mathrm{SEIA}+2.9 \times 10^{-4} \times \text { Dist_Cen }\end{array}$ & 0.63 & 1785 \\
\hline
\end{tabular}


Table 2. Cont.

\begin{tabular}{|c|c|c|c|}
\hline Buffer Size & \multirow{2}{*}{ Model } & Adj. & \multirow{2}{*}{ DF } \\
\hline (m) & & R-Square & \\
\hline \multicolumn{4}{|c|}{ Area 4} \\
\hline 500 & $\begin{array}{l}\text { Log }(\text { LandPrice })=14+1.4 \times \text { NDRA }+4.5 \times 10^{-4} \times \text { NDRA_G }+6.2 \times 10^{-4} \times \\
\text { Dist_sub }-0.1 \times \text { URD }-0.7 \times \mathrm{MMD}+0.6 \times \mathrm{REIZ}+0.2 \times \mathrm{SEIA}-0.5 \times \mathrm{SF}- \\
1.4 \times 10^{-3} \times \text { Dist_Cen }\end{array}$ & 0.75 & 612 \\
\hline 1000 & $\begin{array}{l}\log (\text { LandPrice })=14+1.5 \times \mathrm{NDRA}+6.6 \times 10^{-4} \times \mathrm{NDRA} G \mathrm{G}-1.0 \times 10^{-4} \times \\
\text { Dist_sub }-0.16 \times \mathrm{URD}-0.8 \times \mathrm{MMD}+0.51 \times \mathrm{REIZ}+0.16 \times \mathrm{SEIA}-0.4 \times \mathrm{SF} \\
-5.6 \times 10^{-4} \times \text { Dist_Cen }\end{array}$ & 0.8 & 2614 \\
\hline 500-1000 & $\begin{array}{l}\log (\text { LandPrice })=14+1.5 \times \mathrm{NDRA}+8.9 \times 10^{-4} \times \mathrm{NDRA} \text {.G }-2.0 \times 10^{-4} \times \\
\text { Dist_sub }-0.16 \times \mathrm{URD}-0.78 \times \mathrm{MMD}+0.37 \times \mathrm{REIZ}+0.12 \times \mathrm{SEIA}-0.47 \times \\
\mathrm{SF}-4.5 \times 10^{-4} \times \text { Dist_Cen }\end{array}$ & 0.81 & 2111 \\
\hline
\end{tabular}

NDRA*GL: interaction term between NDRA and distance from DRA line; and DF: degree of freedom.

According to the results of the regression analysis, NDRA was statistically significant at a 0.01 significance level in all models. The sign of the NDRA's coefficient was positive $(+)$ in all models and, therefore, if the land was located within the NDRA, it had a positive effect on the land price. Based on the models, when calculating the compounded growth rate (1) of the models in all areas, if the land was located within NDRA, it was expected that the land price would surge from a minimum of $122 \%$ to a maximum of $802 \%$ of the land price in the targeted areas. Regarding the distance from the greenbelt line, it was significant in all models and the coefficient of NDRA*GL was also positive $(+)$ in all models except in Area 1. This indicated that the greater the distance from the greenbelt line, the higher the land price in the NDRA. On the other hand, distance from the nearest subway station was not significant and signs of the coefficient differed depending on the area. It was found that the urban renewal district and mountain management district had a negative impact on the land price, with the exception of URD in Area 1. Residential environment improvement zones (REIZs) can increase the land price based on the results above. A good school environment also contributed to an increase in the land price, while public culture and sports facilities did not. Unexpectedly, it was found that space facilities did not increase the land price in the study area according to the results. The results also showed that the farther away from the city hall, the lower the land price.

To evaluate the robustness of regression models, the RMSE, MAPE, MASE, and AIC of the models were observed. RMSE is frequently used to measure the differences between values predicted by a model and the values observed. Generally, a lower value is better than a higher one. MAPE is one of the most common metrics to measure the forecasting accuracy of a model. The lower the value for MAPE, the better a model is able to forecast values and the lowest MASE is the preferred method as well [68]. The results showed that the RMSE value was low, except for the $500 \mathrm{~m}$ buffer model in Area 3, which showed the highest value among the models. The MAPE value of the regression analysis was a minimum of $3.16 \%$ in Area 1 to a maximum of $7.1 \%$ in Area 2. Based on the values of each indicator, except AIC, the $500 \mathrm{~m}$ buffer model was the worst model, while the $1000 \mathrm{~m}$ and 500-1000 m models in Area 4 might be better than the other models. In the case of AIC, models with a small buffer $(500 \mathrm{~m})$ showed low AIC as shown in Table 3. 
Table 3. Robustness of the models.

\begin{tabular}{|c|c|c|c|c|}
\hline Buffer Size (m) & $\begin{array}{c}\text { RMSE } \\
\text { (Root Mean of } \\
\text { Squared Errors) }\end{array}$ & $\begin{array}{c}\text { MAPE } \\
\text { (Mean of Absolute } \\
\text { Percentage Errors) }\end{array}$ & $\begin{array}{c}\text { MASE } \\
\text { (Mean of Absolute } \\
\text { Scaled Errors) }\end{array}$ & AIC \\
\hline \multicolumn{5}{|c|}{ Area 1} \\
\hline 500 & 0.53 & 3.16 & 0.50 & 1960 \\
\hline 1000 & 0.60 & 3.76 & 0.44 & 7999 \\
\hline 500-1000 & 0.61 & 3.78 & 0.41 & 6134 \\
\hline \multicolumn{5}{|c|}{ Area 2} \\
\hline 500 & 0.71 & 4.49 & 0.69 & 1928 \\
\hline 1000 & 0.70 & 4.38 & 0.63 & 4873 \\
\hline 500-1000 & 0.67 & 4.07 & 0.58 & 3165 \\
\hline \multicolumn{5}{|c|}{ Area 3} \\
\hline 500 & 1.10 & 7.10 & 0.80 & 2554 \\
\hline 1000 & 0.90 & 5.61 & 0.66 & 6437 \\
\hline $500-1000$ & 0.89 & 5.55 & 0.63 & 4677 \\
\hline \multicolumn{5}{|c|}{ Area 4} \\
\hline 500 & 0.63 & 3.81 & 0.44 & 1203 \\
\hline 1000 & 0.61 & 3.59 & 0.38 & 4875 \\
\hline $500-1000$ & 0.59 & 3.49 & 0.36 & 3816 \\
\hline
\end{tabular}

\subsection{Comparison of Land Price}

The difference in land price within the buffer in Area 1 was USD $1207 / \mathrm{m}^{2}$ for a $500 \mathrm{~m}$ buffer, USD $1097 / \mathrm{m}^{2}$ for a $1000 \mathrm{~m}$ buffer, and USD $1044 / \mathrm{m}^{2}$ for a buffer of between 500 and $1000 \mathrm{~m}$. The difference in land price in Area 2 was USD $677 / \mathrm{m}^{2}$, USD $665 / \mathrm{m}^{2}$, and USD $677 / \mathrm{m}^{2}$ for the $500 \mathrm{~m}, 1000 \mathrm{~m}$, and $500-1000 \mathrm{~m}$ buffers, respectively, while in Area 3 it was USD $760 / \mathrm{m}^{2}$, USD $723 / \mathrm{m}^{2}$, and USD $744 / \mathrm{m}^{2}$, and in Area 4 it was USD $838 / \mathrm{m}^{2}$, USD $1028 / \mathrm{m}^{2}$, and USD $1082 / \mathrm{m}^{2}$ as shown in Tables 4 and 5 .

The difference in land prices in areas located closer to the more developed Dong-gu, such as Area 1 and Area 4, were found to be larger, whereas the difference in land price was much smaller in places far from New Town, such as Area 2 and Area 3 in Deokyang-gu. When looking at the average land price shown in each buffer, the difference in the average land price was USD $1116 / \mathrm{m}^{2}$ in Area 1, USD $673 / \mathrm{m}^{2}$ in Area 2, USD $713 / \mathrm{m}^{2}$ in Area 3, and USD $983 / \mathrm{m}^{2}$ in Area 4.

In this study, the effect of the greenbelt on land price was calculated based on differences between land prices in the DRA. The difference between the average land prices in the target area was USD $871 / \mathrm{m}^{2}$. In addition, it amounted to USD 110 billion for the entire DRA as shown in Table 6.

Through GIS analysis, the difference between the land price within the DRA and the land price within and outside the DRA from Area 1 to Area 4 was calculated. Next, the average difference between the total land prices in Goyang city was calculated. When this average difference was assumed to affect land prices due to the designation of the DRA, the amount was found to reach USD 110 billion when applied to the entire DRA in Goyang city.

If only $50 \%$ was taken into consideration, the difference from the decision price was USD 55 billion. If 30\% was assumed, the difference from the decision price was USD 33 billion. Even if only $10 \%$ of the land price was reflected, the price in the DRA was found to be different by USD 11 billion from the land price in the developed area, as shown in Table 7. 
Table 4. Land price in the targeted areas.

\begin{tabular}{|c|c|c|c|}
\hline $\begin{array}{l}\text { Buffer Size } \\
\text { (m) }\end{array}$ & $\begin{array}{l}\text { Average in GB } \\
\left(\mathrm{USD} / \mathrm{m}^{2}\right)\end{array}$ & $\begin{array}{c}\text { Average Outside of GB } \\
\left(\mathrm{USD} / \mathrm{m}^{2}\right)\end{array}$ & $\begin{array}{c}\text { Difference in Average } \\
\left(\mathrm{USD} / \mathrm{m}^{2}\right)\end{array}$ \\
\hline \multicolumn{4}{|c|}{ Area 1} \\
\hline 500 & 108 & 1316 & 1207 \\
\hline 1000 & 107 & 1204 & 1097 \\
\hline 500-1000 & 107 & 1204 & 1044 \\
\hline \multicolumn{4}{|c|}{ Area 2} \\
\hline 500 & 266 & 932 & 677 \\
\hline 1000 & 237 & 914 & 665 \\
\hline 500-1000 & 223 & 900 & 677 \\
\hline \multicolumn{4}{|c|}{ Area 3} \\
\hline 500 & 179 & 849 & 760 \\
\hline 1000 & 151 & 874 & 723 \\
\hline 500-1000 & 138 & 882 & 744 \\
\hline \multicolumn{4}{|c|}{ Area 4} \\
\hline 500 & 187 & 1025 & 838 \\
\hline 1000 & 166 & 1194 & 1028 \\
\hline 500-1000 & 159 & 1242 & 1082 \\
\hline
\end{tabular}

GB: greenbelt.

Table 5. Differences in land price based on area and buffer size.

\begin{tabular}{|c|c|c|c|c|}
\hline Area & $\begin{array}{c}\text { Difference in Land Price } \\
\text { Within } 500 \mathrm{~m} \text { Buffer } \\
\left(\mathrm{USD} / \mathrm{m}^{2}\right)\end{array}$ & $\begin{array}{c}\text { Difference in Land Price } \\
\text { Within } 1000 \mathrm{~m} \text { Buffer } \\
\left(\mathrm{USD} / \mathrm{m}^{2}\right)\end{array}$ & $\begin{array}{c}\text { Difference in } \\
\text { Land Price Within } \\
500-1000 \mathrm{~m} \text { Buffer } \\
\left(\mathrm{USD} / \mathrm{m}^{2}\right)\end{array}$ & $\begin{array}{l}\text { Average Difference in } \\
\text { Land Price } \\
\left(\mathrm{USD} / \mathrm{m}^{2}\right)\end{array}$ \\
\hline Area 1 & 1207 & 1097 & 1044 & 1116 \\
\hline Area 2 & 665 & 677 & 677 & 673 \\
\hline Area 3 & 670 & 723 & 744 & 713 \\
\hline Area 4 & 838 & 1028 & 1082 & 983 \\
\hline
\end{tabular}

Table 6. Estimated difference in land price.

\begin{tabular}{cc}
\hline Average difference in land price in Areas 1-4 & USD $871 / \mathrm{m}^{2}$ \\
\hline Difference in land price in greenbelt & USD 110 billion \\
\hline
\end{tabular}

Table 7. Adjusted difference in land price (unit: USD billion).

\begin{tabular}{cccc}
\hline Areas & $\mathbf{5 0 \%}$ & $\mathbf{3 0} \%$ & $\mathbf{1 0} \mathbf{0}$ \\
\hline Area 1 & 71 & 42 & 14 \\
\hline Area 2 & 43 & 26 & 9 \\
\hline Area 3 & 45 & 27 & 9 \\
\hline Area 4 & 62 & 37 & 12 \\
\hline Greenbelt area & 55 & 33 & 11 \\
\hline
\end{tabular}


To examine the adequacy of the difference in the decided land price derived from the analysis results, we compared the difference between the regions recently lifted from the DRA in Goyang city and the published land price before and after the release of the DRA in that region.

Jugyo-dong and Samsong-dong districts 1 and 2 were selected as target areas. To examine land price changes due to the release of the DRA, the average comparison was conducted in the areas of Jugyo-dong, Samsong-dong 1, and Samsong-dong 2 that were lifted in 2007. To minimize the impact of land price speculation or bubbles that may have occurred due to the release of the DRA, and to examine the effect of the correct land, the price was taken from 5 years before and 5 years after the release of the DRA. Changes in land prices were investigated.

The average value for the three regions was obtained by calculating the difference in the land prices between 2002-2007 and 2008-2013 in these regions as shown in Table 8. As a result of the analysis, the difference in the average land price of the three regions was found to be USD $839 / \mathrm{m}^{2}$, which was not significantly different from the average land price difference of USD $871 / \mathrm{m}^{2}$ for Areas 1 to 4 . The results of this study showed that the difference between the published land price within the DRA and the publicly announced land price outside the DRA was consistent, indicating that the results of the analysis were reasonable.

Table 8. Difference in land prices between 2007 and 2008.

\begin{tabular}{cc}
\hline Area & Difference in Land Price (USD/m ${ }^{\mathbf{2}}$ ) \\
\hline Jugyo-dong, & 698 \\
\hline Samsong-dong 1 & 985 \\
\hline Samsong-dong 2 & 833 \\
\hline Average & 839 \\
\hline
\end{tabular}

\section{Conclusions}

This study aimed to consider the effects of DRAs, reflecting realistic land prices in the land use management of metropolitan areas, including a management plan and comprehensive plan related to the DRA.

To examine the impact of the DRA on the publicly announced land price, this study estimated the regression models based on the targeted areas and buffers. Moreover, we examined the difference between the land price determined within the DRA and the land price outside of the DRA using spatial analysis. Based on the regression results, it was found that if the land was designated as a DRA, the land price dropped. Conversely, if the land was lifted from the DRA, it was expected that its price would dramatically increase. One plausible reason for this might be the increased expectations that when greenbelts are lifted, it might raise investment potential [56]. Regarding the effects of the distance from the greenbelt line, the results revealed that the distance had a positive effect on the land price in the area where it was not designated as a DRA. This might be explained as the farther away from the greenbelt line, the closer to the city center, the higher the land price. This represents the preferences of people who want to live inside the city rather than on its periphery [58]. The distance from the subway station was not significant. The possible reason was that the target area was far from the subway station with the exception of one area. In these areas, it was inconvenient to not have personal transportation and, so, people did not rely much on public transportation.

There was a significant difference in land prices in the inner and outer areas of the greenbelt. Land prices in the outer area of the greenbelt were much higher than those of the inner area. The results of the analysis are consistent with other previous studies $[53,55]$, though not with all $[49,52]$. Since the greenbelt is considered to be a form of strict restriction of property rights, the designation of the greenbelt means depriving landowners of property rights. Therefore, it causes dissatisfaction with landlords and inconvenience to residents. In particular, as development pressure increases due to the increase in the population of 
metropolitan areas in South Korea, these development restrictions are causing backlash from affected local governments, landlords, and residents. As Jun [69] suggested, the greenbelt release might increase the number of residents and jobs in greenbelt zones, and rents for residential and non-residential space might decline for the whole metropolitan area since greenbelts limit land supply for development and cause rents to increase.

The buffer function in GIS was used for the analysis, and USD $871 / \mathrm{m}^{2}$ was derived as the difference in the average land price of the target areas. To examine the applicability of the price to the real world, we compared and calculated the difference in the chosen location of the areas that were recently lifted from the greenbelt, and the results seemed to suggest that the analysis result was reasonable. When the difference in the average land price was applied to the entire DRA of Goyang city, it was set as USD 110 billion when $100 \%$ was applied, USD 55 billion when 50\% was applied, and USD 12 billion when only $10 \%$ was applied. Assuming that the publicly announced land price of Goyang city was largely affected by the DRA, the difference in the publicly announced land price can be considered as the economic effect of the DRA on the land price.

According to the results of this study, there was little difference in price as a result of different distances of between $500 \mathrm{~m}$ and $1000 \mathrm{~m}$. On the other hand, it was found that the difference in land price between the more developed area and land adjacent to it was much larger than the difference between the less developed area and it's adjacent area. The reason why the greenbelt's land price close to the more developed areas is higher may be due to the reflection of more expectations for greenbelt release and development. It reflects people's expectations for the development profits generated when the greenbelt is lifted and landowner's property rights are restored.

\section{Discussion}

Although the total size of the greenbelt in South Korea continues to decrease, there are places around the world where greenbelts are established and continuing to increase in size [66], thus the issue of greenbelts is not homogeneous, but due to regional specificity, such as each country's socio-economic circumstances and unique politics [70].

The current trend is that green areas are recognized worldwide as providing amenities to urban residents and bringing positive effects to surrounding properties. Its importance has also increased in recent years, playing a positive and important role in helping people physically and emotionally in overcoming the Covid-19 outbreak [27-29,39-44]. However, when a greenbelt is established, the people most affected by it are the landowners and officials within the greenbelt that are directly regulated. While not a greenbelt, but nonetheless a similar example, the Urban Park Sunset Law in South Korea will cancel the designation of nearly $583 \mathrm{~km}^{2}$ of publicly appropriated private land for urban parks, which will be released and returned to private owners by 2020 [71]. Local governments need to establish information on land prices in natural parks or DRAs. This study focused on predicting the land price within the greenbelt to help local governments prepare for land compensation costs caused by the Urban Park Sunset system as well.

The results, if judged only by the difference in land price, might suggest that the cost of land affected by the regulation of land use is higher than the positive impact of the greenbelt. Unlike in the UK, which centrally leads the greenbelt policy, or the USA, which is controlled by local governments, Korea is a hybrid case in which the central and local governments control and manage together [69]. These characteristics may also have an impact on outcomes that differ from cases in other countries. It is well known that greenbelts have a positive effect on the prices of buildings and land around them, and also on citizens themselves, such as by contributing to health and wellbeing [21,22], reducing the heat island effect $[24,25]$, lowering racial disparity in infection rates [27], and playing various functions in overcoming the COVID-19 pandemic [28-30]. However, there are few results as to whether it has a positive effect on land prices within the greenbelt. The results of this study, with its robust regression models, suggested that, although the greenbelt has many positive effects, it can also have a negative effect on land prices if regulations on land 
use become too strict. This study, using the case of South Korea, can be used as an example of this issue.

These results suggest that policymakers are able to use green infrastructure, such as DRAs, to improve the urban environment and control urban sprawl, but it must be used as a part of an integrative package that includes other economic and social tools in the future. On the other hand, the price of land within the greenbelt remains low due to restrictions on use, but when the greenbelt is lifted, the price increases significantly. Therefore, the designation of DRA, which can significantly affect land prices, should be carefully decided as they can become a target of land speculation due to these characteristics. Above all, in the sustainable management of cities through regulations such as the greenbelt, these findings will also be reflected and help to establish an inclusive land management policy. Regarding the controversy over greenbelts, one solution might be for the state to buy the ownership of the land in the greenbelt, like in [18]. This study also provides an opportunity to estimate the costs that can be incurred when the central government acquires the greenbelt.

There are limitations to this study. The land price was based on the published land price, not on the actual land sales price. This is because, due to strict land regulations, land transactions were rarely carried out, and sufficient data to form actual land transaction prices were not collected. Therefore, the actual price difference between the land inside and outside the greenbelt is expected to be greater. Furthermore, studies using more accurate land prices and ownership status reflecting local conditions are needed. Additionally, a more detailed and accurate analysis, such as using the coefficient of determination (COD), with the land price detected may be needed.

Due to these shortcomings, there are more opportunities for further research. Above all, additional research should be conducted regarding the comparison of the benefits with the costs of greenbelts, and research that can utilize this in land management by policymakers should be conducted.

Author Contributions: Writing-original draft preparation, D.L.; supervision, C.C. All authors have read and agreed to the published version of the manuscript.

Funding: This research received no external funding.

Institutional Review Board Statement: Not applicable.

Informed Consent Statement: Not applicable.

Data Availability Statement: Not applicable.

Acknowledgments: We would like to express our gratitude to the Goyang city government for sharing the land price and GIS data for Goyang city.

Conflicts of Interest: The authors declare no conflict of interest.

\section{References}

1. Bengston, D.; Youn, Y. Urban containment policies and the protection of natural areas: The case of Seoul's greenbelt. Ecol. Soc. 2006, 11, 3. [CrossRef]

2. Banerjee, S.; Palit, D.; Roy, P. Assessment of vegetation under air pollution stress in urban industrial area for greenbelt development. Int. J. Environ. Sci. Technol. 2019, 16, 5857-5870. [CrossRef]

3. Konijnendijk, C.C. The Role of Forestry in the Development and Reform of Green Belts. Plan. Pract. Res. 2010, $25,241-254$. [CrossRef]

4. Kardani-Yazd, N.; Kardani-Yazd, N.; Daneshvar, M. Strategic spatial analysis of urban greenbelt plans in Mashhad city, Iran. Environ. Syst. Res. 2019, 8, 30. [CrossRef]

5. Fitzsimons, J.; Pearsonb, C.J.; Lawsona, C.; Hill, M.J. Evaluation of land-use planning in greenbelts based on intrinsic characteristics and stakeholder values. Landsc. Urban Plan. 2012, 106, 23-34. [CrossRef]

6. Cadieux, K.V.; Taylor, L.E.; Bunce, M.F. Landscape ideology in the Greater Golden Horseshoe Greenbelt Plan: Negotiating material landscapes and abstract ideals in the city's countryside. J. Rural Stud. 2013, 32, 307-319. [CrossRef]

7. Aguado, I.; Barrutia, J.M.; Echebarria, C. The green belt of Vitoria-Gasteiz. A successful practice for sustainable urban planning. Boletín Asociación Geógrafos Españoles 2013, 61, 181-193.

8. Smiraglia, D.; Salvati, L.; Egidi, G.; Salvia, R.; Giménez-Morera, A.; Halbac-Cotoara-Zamfir, R. Toward a New Urban Cycle? A Closer Look to Sprawl, Demographic Transitions and the Environment in Europe. Land 2021, 10, 127. [CrossRef] 
9. Lityński, P.; Hołuj, A. Macroeconomic Perspective on Urban Sprawl: A Multidimensional Approach in Poland. Land 2021, 10, 116. [CrossRef]

10. Kim, S.-B. The Role of Government in the Redistribution of Property Rights: The Case of the Korean Greenbelt. Int. Rev. Public Adm. 2004, 9, 97-111. [CrossRef]

11. Kim, J.I.; Hyun, J.Y.; Lee, S.G. The Effects of Releasing Greenbelt Restrictions on Land Development in the Case of Medium-Sized Cities in Korea. Sustainability 2019, 11, 630. [CrossRef]

12. Lee, C.; Linnenman, P. Dynamics of the greenbelt amenity effect on the land market: The case of Seoul's greenbelt. Real Estate Econ. 1998, 26, 107-129. [CrossRef]

13. Vongpraseuth, T.; Seong, E.Y.; Shin, S.; Kim, S.H.; Choi, C.G. Hope and reality of new towns under greenbelt regulation: The case of self-containment or transit-oriented metropolises of the first-generation new towns in the Seoul Metropolitan Area, South Korea. Cities 2020, 102, 102699. [CrossRef]

14. Willis, K.; Whitby, M. The value of green belt land. J. Rural Stud. 1985, 1, 147-162. [CrossRef]

15. Verheye, W.H. (Ed.) The value and price of land. In Land Use, Land Cover and Soil Sciences; UNESCO-EOLSS Publishers: Oxford, UK, 2007.

16. Williams, E.; Gottfried, R.R.; Brockett, C.D.; Evans, J.P. An integrated analysis of the effectiveness of Tennessee's Forest Greenbelt Program. Landsc. Urban Plan. 2004, 69, 287-297. [CrossRef]

17. Pond, D. Ontario's greenbelt: Growth management, farmland protection, and regime change in southern Ontairo. Can. Public Policy 2009, 35, 413-432.

18. Greenbelt Coalition of Canada's Capital Region. Greenbelt Coalition's Position Paper for the NCC's Greenbelt Master Plan Review. 2010. Available online: http://greenspace-alliance.ca/index.php/archives-nccfederal-government/greenbelt-masterplan-review-2/greenbelt-coalition-position-paper/ (accessed on 21 June 2021).

19. Krajewska, M.; Źróbek, S.; Kovač, M.Š. The Role of Spatial Planning in the Investment Process in Poland and Slovenia. Real Estate Manag. Valuat. 2014, 22, 52-66. [CrossRef]

20. London Green Belt Council Protecting London's Green Belt. Available online: http://londongreenbeltcouncil.org.uk/ (accessed on 29 April 2021).

21. Swanwick, C.; Dunnett, N.; Woolley, H. Nature, Role and Value of Green Space in Towns and Cities: An Overview. Built Environ. 2003, 29, 94-106. [CrossRef]

22. Liu, O.Y.; Russo, A. Assessing the contribution of urban green spaces in green infrastructure strategy planning for urban ecosystem conditions and services. Sustain. Cities Soc. 2021, 68, 102772. [CrossRef]

23. Leveau, L.M. Big cities with small green areas hold a lower species richness and proportion of migrant birds: A global analysis. Urban For. Urban Green. 2021, 57, 126953. [CrossRef]

24. Tan, X.; Sun, X.; Huang, C.; Yuan, Y.; Hou, D. Comparison of cooling effect between green space and water body. Sustain. Cities Soc. 2021, 67, 102711. [CrossRef]

25. Kaplan, G. Evaluating the roles of green and built-up areas in reducing a surface urban heat island using remote sensing data. Urbani Izziv 2019, 30, 105-112. [CrossRef]

26. Bonilla-Bedoya, S.; Estrella, A.; Santos, F.; Herrera, M.Á. Forests and urban green areas as tools to address the challenges of sustainability in Latin American urban socio-ecological systems. Appl. Geogr. 2020, 125, 102343. [CrossRef]

27. Lu, Y.; Chen, L.; Liu, X.; Yang, Y.; Sullivan, W.; Xu, W.; Webster, C.; Jiang, B. Green spaces mitigate racial disparity of health: A higher ratio of green spaces indicates a lower racial disparity in SARS-CoV-2 infection rates in the USA. Environ. Int. 2021, 152, 106465. [CrossRef]

28. Ugolini, F.; Massetti, L.; Calaza-Martínez, P.; Cariñanos, P.; Dobbs, C.; Ostoić, S.K.; Marin, A.M.; Pearlmutter, D.; Saaroni, H.; Šaulienè, I.; et al. Effects of the COVID-19 pandemic on the use and perceptions of urban green space: An international exploratory study. Urban For. Urban Green. 2020, 56, 126888. [CrossRef] [PubMed]

29. Burnett, H.; Olsen, J.R.; Nicholls, N.; Mitchell, R. Change in time spent visiting and experiences of green space following restrictions on movement during the COVID-19 pandemic: A nationally representative cross-sectional study of UK adults. BMJ Open 2021, 11, e044067. [CrossRef] [PubMed]

30. Heo, S.; Lim, C.; Bell, M. Relationships between Local Green Space and Human Mobility Patterns during COVID-19 for Maryland and California, USA. Sustainability 2020, 12, 9401. [CrossRef]

31. Benítez, G.; Alvarado-Castillo, G.; Palestina, R.A.; Cortés, M.; Williams, K.; Acosta, I. Designing a green belt for Xalapa City: Veracruz under current Mexican policies. Reg. Cohes. 2018, 8, 94-115. [CrossRef]

32. Akimowicz, O.; Cummings, H.; Landman, K. Green lights in the Greenbelt? A qualitative analysis of farminvestment decisionmaking in peri-urban Southern Ontario. Land Use Policy 2016, 55, 24-36. [CrossRef]

33. Akimowicz, M.; Vyn, R.J.; Cummings, H.; Landman, K. An introduction to mixed methods research in agricultural economics: The example of farm investment in Ontario's Greenbelt, Canada. J. Rural Stud. 2018, 61, 162-235. [CrossRef]

34. Semeraro, T.; Scarano, A.; Buccolieri, R.; Santino, A.; Aarrevaara, E. Planning of Urban Green Spaces: An Ecological Perspective on Human Benefits. Land 2021, 10, 105. [CrossRef]

35. Macdonald, S.; Keil, R. The Ontario Greenbelt: Shifting the Scales of the Sustainability Fix? Prof. Geogr. 2012, 64, 125-145. [CrossRef] 
36. Amati, M.; Yokohari, M. Temporal changes and local variations in the functions of London's green belt. Landsc. Urban Plan. 2006, 75, 125-142. [CrossRef]

37. Yang, J.; Jinxing, Z. The failure and success of greenbelt program in Beijing. Urban For. Urban Green. 2007, 6, 287-296. [CrossRef]

38. Siedentop, S.; Fina, S.; Krehl, A. Greenbelts in Germany's regional plans-An effective growth management policy? Landsc. Urban Plan. 2016, 145, 71-82. [CrossRef]

39. Wang, H.-B.; Li, H.; Ming, H.-B.; Hu, Y.-H.; Chen, J.-K.; Zhao, B. Past land use decisions and socioeconomic factors influence urban greenbelt development: A case study of Shanghai, China. Landsc. Ecol. 2014, 29, 1759-1770. [CrossRef]

40. Xie, X.; Kang, H.; Behnisch, M.; Baildon, M.; Krüger, T. To what extent can the green belts prevent urban sprawl?-A comparative study of frankfurt am Main, London and Seoul. Sustainability 2020, 12, 679. [CrossRef]

41. World Health Organization Regional Office for Europe. Urban Green Spaces: A Brief for Action. 2017. Available online: https://www.euro.who.int/_data/assets/pdf_file/0010/342289/Urban-Green-Spaces_EN_WHO_web3.pdf (accessed on 21 June 2021).

42. Salbitano, F.; Borelli, S.; Conigliaro, M.; Chen, Y. Guidelines on Urban and Peri-Urban Forestry; FAO Forestry Paper No. 178; FAO: Rome, Italy, 2016.

43. Asabere, P.K.; Huffman, F.E. The Relative Impacts of Trails and Greenbelts on Home Price. J. Real Estate Financ. Econ. 2009, 38, 408-419. [CrossRef]

44. Yoon, H. When and where do we see the proximity effect of a new park?-A case study of the Dream Forest in Seoul, Korea. $J$ Environ. Plan. Manag. 2018, 61, 1113-1136. [CrossRef]

45. Jung, E.; Choi, Y.; Yoon, H. The impact of the Gyeongui Line Park project on residential property values in Seoul, Korea. Habitat Int. 2016, 58, 108-117. [CrossRef]

46. Nicholls, S.; Crompton, J.L. The Impact of Greenways on Property Values: Evidence from Austin, Texas. J. Leis. Res. 2005, 37, 321-341. [CrossRef]

47. Netusil, N.R. The Effect of Environmental Zoning and Amenities on Property Values: Portland, Oregon. Land Econ. 2005, 81, 227-246. [CrossRef]

48. Vyn, R.J. The Effect of Agricultural Zoning on Rural Residential Property Values: An Application to Ontario's Greenbelt. Can. J. Agric. Econ. 2015, 63, 281-307. [CrossRef]

49. Bono, H.R.; Gezon, L.L.; Smith, W.J.; Walker, M.D. The Impact of the Carrollton GreenBelt on Residential Housing Prices: A Spatial Approach. Coast. Bus. J. 2018, 16, 1-16.

50. Bockarjova, M.; Botzen, W.; van Schie, M.; Koetse, M. Property price effects of green interventions in cities: A meta-analysis and implications for gentrification. Environ. Sci. Policy 2020, 112, 293-304. [CrossRef]

51. Anderson, S.T.; West, S.E. Open space, residential property values, and spatial context. Reg. Sci. Urban Econ. 2006, 36, 773-789. [CrossRef]

52. Czembrowski, P.; Łaszkiewicz, E.; Kronenberg, J.; Engström, G.; Andersson, E. Valuing individual characteristics and the multifunctionality of urban green spaces: The integration of sociotope mapping and hedonic pricing. PLoS ONE 2019, 14, e0212277. [CrossRef]

53. Daams, M.N.; Sijtsma, F.J.; Van der Vlist, A. The Effect of Natural Space on Nearby Property Prices: Accounting for Perceived Attractiveness. Land Econ. 2016, 92, 389-410. [CrossRef]

54. Morancho, A.B. A hedonic valuation of urban green areas. Landsc. Urban Plan. 2003, 66, 35-41. [CrossRef]

55. Kim, H.-S.; Lee, G.-E.; Lee, J.-S.; Choi, Y. Understanding the local impact of urban park plans and park typology on housing price: A case study of the Busan metropolitan region, Korea. Landsc. Urban Plan. 2019, 184, 1-11. [CrossRef]

56. Lee, S.; Yoon, H. Effects of greenbelt cancellation on land value: The case of Wirye New Town, South Korea. Urban For. Urban Green. 2019, 41, 55-66. [CrossRef]

57. Deaton, B.J.; Vyn, R.J. The effect of strict agricultural zoning on agricultural land values: The case of Ontario's greenbelt. Am. J. Agric. Econ. 2010, 92, 941-955. [CrossRef]

58. Herath, S.; Choumert, J.; Maier, G. The value of the greenbelt in Vienna: A spatial hedonic analysis. Ann. Reg. Sci. 2015, 54, 349-374. [CrossRef]

59. Morano, P.; Guarini, M.R.; Tajani, F.; Di Liddo, F.; Anelli, D. Incidence of different types of urban green spaces on property prices. A case study in the Flaminio District of Rome (Italy). In Computational Science and Its Applications_ICCSA 2019; Misra, S., Gervasi, O., Murgante, B., Stankova, E., Korkhov, V., Torre, C., Rocha, A.M.A.C., Taniar, D., Apduhan, B.O., Tarantino, E., Eds.; Springer: Cham, Switzerland, 2019; Volume 11622. [CrossRef]

60. Han, H.; Huang, C.; Ahn, K.-H.; Shu, X.; Lin, L.; Qiu, D. The Effects of Greenbelt Policies on Land Development: Evidence from the Deregulation of the Greenbelt in the Seoul Metropolitan Area. Sustainability 2017, 9, 1259. [CrossRef]

61. Ministry of Land, Infrastructure and Transport. Available online: http://www.molit.go.kr/USR/policyData/m_34681/dtl?id=67 (accessed on 21 June 2021).

62. Kwon, Y.; Kwon, I.; Lee, Y.; Jang, H. Development Restricted Area; Communicationbooks: Seoul, Korea, 2020. 
63. Ministry of Land, Infrastructure and Transport. Restricted Development Zone Designation. Available online: http: / / stat.molit.go.kr/portal/ cate/ statMetaView.do?hRsId=18\&hFormId=516\&hSelectId=516\&hPoint=00\&hAppr=1\&hDivEng= $\&$ oFileName=\&rFileName=\&midpath=\&month_yn=N\&sFormId=516\&sStart=2020\&sEnd=2020\&sStyleNum=596\&EXPORT= (accessed on 21 June 2021).

64. Goyangcity. Available online: http:/ / www.goyang.go.kr/www/index.do (accessed on 27 February 2021).

65. Crompton, J.L. The impact of parks on property values: Empirical evidence from the past two decades in the United States. Manag. Leis. 2005, 10, 203-218. [CrossRef]

66. Han, A.T.; Go, M.H. Explaining the national variation of land use: A cross-national analysis of greenbelt policy in five countries. Land Use Policy 2019, 81, 644-656. [CrossRef]

67. Econometrics and the Log-Linear Model. Available online: https://www.dummies.com/education/economics/econometrics/ econometrics-and-the-log-linear-model/ (accessed on 4 May 2021).

68. Hyndman, R.; Koehler, A.B. Another look at measures of forecast accuracy. Int. J. Forecast. 2006, 22, 679-688. [CrossRef]

69. Jun, M.-J. The effects of Seoul's greenbelt on the spatial distribution of population and employment, and on the real estate market. Ann. Reg. Sci. 2012, 49, 619-642. [CrossRef]

70. Zepp, H. Regional GrenBelts in the Ruhr region a planning concept revisited in view of ecosystem services. Erdkunde 2018, 72, 1-22. [CrossRef]

71. Kang, S.-J. A Study on the Legal Improvement of Full-scale Park area abolition System. Dong-A Law Rev. 2018, 80, 141-176. [CrossRef] 